the Trump administration's unilateral efforts to enact snapback sanctions and committed, if elected, to rejoin the JCPOA provided that Iran strictly complies with the agreement. ${ }^{52}$

\title{
Congress and the Trump Administration Spar Over U.S. Arms Sales to the Saudi-Led Coalition in Yemen
}

doi:10.1017/ajil.2020.102

Longstanding tensions between Congress and the executive over U.S. support to the Saudiled coalition in Yemen have spurred conflict between the branches over arms sales. In May 2019, U.S. Secretary of State Michael Pompeo declared an emergency under the Arms Export Control Act (AECA) to bypass congressional "freezes" on arms sales and complete $\$ 8.1$ billion in sales to members of the Saudi-led coalition. In response, Congress requested that the State Department inspector general (IG) investigate the matter. In a report released in August 2020, the IG determined that the emergency declaration comported with the AECA's procedural requirements but that the State Department's risk assessments and civilian casualty mitigation measures did not fully address legal concerns about the sales. The Trump administration has continued to move forward with arms sales, including by unilaterally reinterpreting a nonbinding multilateral export control regime to eliminate prohibitions on the export of certain unmanned aerial systems (UAS). A bipartisan group of legislators has introduced a bill to prevent such sales to all countries except select U.S. allies. In September, a UN report criticized U.S. and other countries' arms sales to the Saudi-led coalition and recommended referral of the situation in Yemen to the International Criminal Court (ICC).

The Yemeni government has been engaged in a civil war with Iranian-backed Houthi rebels since late $2014 .{ }^{1}$ In March 2015, a Saudi-led international coalition entered the conflict to assist the Yemeni government, and the United States began providing the coalition with logistical support, intelligence sharing, and arms. ${ }^{2}$ The United States has stopped short of joining the Saudi-led coalition or taking direct action against the Houthis in support of the Yemeni government. ${ }^{3}$

Flawed Decision to Advance "Snapback" Sanctions on Iran (Aug. 21, 2020), at https://www.cardin.senate.gov/ newsroom/press/release/cardin-statement-on-trump-administrations-flawed-decision-to-advance-snapback-sanctions-on-iran [https://perma.cc/5HY4-34GW].

52 Joe Biden, Joe Biden: There's a Smarter Way to Be Tough on Iran, CNN (Sept. 13, 2020), at https://www.cnn. com/2020/09/13/opinions/smarter-way-to-be-tough-on-iran-joe-biden/index.html.

${ }^{1}$ Off. of Inspector Gen., U.S. Dep't of State, ISP-I-20-19, Review of the Department of State's Role in Arms Transfers to the Kingdom of Saudi Arabia and the United Arab Emirates 2, 4 (2020), available at https://www.stateoig.gov/system/files/isp-i-20-19.pdf [https://perma.cc/975Q-HFVK].

${ }_{2}^{2} I d$. For additional background on the U.S. role in the conflict, see Kristina Daugirdas \& Julian Davis Mortenson, Contemporary Practice of the United States, 111 AJIL 476, 523-33 (2017); Jean Galbraith, Contemporary Practice of the United States, 113 AJIL 131, 159-69 (2019).

${ }^{3}$ Off. of Inspector Gen., supra note 1, at 4; Daugirdas \& Mortenson, supra note 2, at 523-27. 
Congress has consistently expressed concern over the U.S. role, due largely to the high rate of civilian casualties resulting from coalition airstrikes with U.S.-supplied arms. ${ }^{4}$ As early as 2016, Congress considered resolutions to block arms sales to Saudi Arabia, ${ }^{5}$ but the Obama administration voluntarily limited its support to the Saudi-led coalition, reducing arms sales and the number of U.S. military advisors in Riyadh. ${ }^{6}$ When President Donald Trump took office, his administration significantly enhanced U.S. support to the Saudi-led coalition, announcing a $\$ 110$ billion arms sale. ${ }^{7}$ This sale prompted additional congressional attempts to limit U.S. involvement, including the introduction of joint resolutions to block specific arms sales. ${ }^{8}$ Though the sale-specific joint resolutions were not adopted, ${ }^{9}$ Congress passed National Defense Authorization Act provisions that established new congressional reporting requirements and prohibited some appropriations unless the secretary of state certified that Saudi Arabia and the United Arab Emirates (UAE) were undertaking actions to reduce collateral damage. ${ }^{10}$

The 2018 killing of journalist Jamal Khashoggi at the Saudi consulate in Istanbul intensified tensions between Congress and the executive over U.S. support to the Saudi-led coalition. ${ }^{11}$ In April 2019, Congress attempted to end U.S. involvement in the Yemeni civil war by passing a joint resolution pursuant to the War Powers Resolution (WPR). ${ }^{12}$ The resolution directed "the President to remove United States Armed Forces from hostilities in or affecting the Republic of Yemen, except United States Armed Forces engaged in operations directed at al Qaeda or associated forces" within thirty days. ${ }^{13}$ This joint resolution "was the first time [WPR] legislation passed Congress with bipartisan support and reached the president's desk." ${ }^{4}$ Trump vetoed the joint resolution, calling it "an unnecessary, dangerous attempt to weaken my constitutional authorities" and arguing that U.S. support to the Saudi-led coalition did not constitute hostilities within the meaning of the WPR. ${ }^{15}$ Congress failed to override the veto by a Senate vote of 53-45 in May 2019. ${ }^{16}$

\footnotetext{
${ }^{4}$ Off. of Inspector Gen., supra note 1, at 1. For a detailed description of congressional action on the Yemeni civil war since 2015, see Jeremy M. Sharp, Christopher M. Blanchard \& Sarah R. Collins, Cong. Research Serv., R45046, Congress and the War in Yemen: Oversight and Legislation 2015-2020 (June 19, 2020), available at https://fas.org/sgp/crs/mideast/R45046.pdf [https://perma.cc/RMP9-KJN].

${ }^{5}$ Daugirdas \& Mortenson, supra note 2, at 531; Sharp, Blanchard \& Collins, supra note 4, at 4-5; H.R.J. Res. 90, 114th Cong. (2016); H.R.J. Res. 98, 114th Cong. (2016); S.J. Res. 32, 114 th Cong. (2016); S.J. Res. 39, 114th Cong. (2016).

${ }^{6}$ Galbraith, supra note 2, at 160-61.

${ }^{7}$ Id.

${ }^{8}$ Id. at 161; Sharp, BlanCHARD \& Collins, supra note 4, at 7-8; S.J. Res 42, 115 th Cong. (2017); H.R.J. Res. 102, 115th Cong. (2017).

${ }^{9}$ Galbraith, supra note 2, at 161; SHARP, BlanCHARD \& Collins, supra note 4, at 7-8.

${ }^{10}$ John S. McCain National Defense Authorization Act for Fiscal Year 2019, Pub. L. No. 115-232, \$\$936, 1062, 1290 (2018). For additional discussion, see Galbraith, supra note 2, at 161-65; SHARP, BlANCHARD \& Collins, supra note 4, at 11-14.

${ }^{11}$ Galbraith, supra note 2, at 168.

${ }^{12}$ S.J. Res. 7, 116th Cong. (2019); see also Mark Landler \& Peter Baker, Trump Vetoes Measure to Force End to U.S. Involvement in Yemen War, N.Y. Times (Apr. 16, 2019), at https://www.nytimes.com/2019/04/16/us/politics/trump-veto-yemen.html.

${ }^{13}$ S.J. Res. 7, 116th Cong. $\$ 2$ (2019).

${ }^{14}$ Landler \& Baker, supra note 12.

${ }^{15}$ Donald J. Trump, Message to the Senate Returning Without Approval Legislation Regarding the Removal of United States Armed Forces from Hostilities in Yemen, 2019 DAILY Comp. Pres. Doc. 002, 27 (Apr. 16, 2019).

${ }^{16}$ U.S. Senate, Vetoes by President Donald J. Trump (2020), at https://www.senate.gov/legislative/vetoes/ TrumpDJ.htm [https://perma.cc/7LZL-5JCG].
} 
Congress has also frozen specific proposed weapons sales to coalition members. The AECA requires the president to notify Congress of certain proposed government-to-government arms sales. ${ }^{17}$ After the president provides formal notice, Congress can attempt to prevent the sale by passing a joint resolution or other legislation, but such actions remain subject to presidential veto. ${ }^{18}$ In addition to those formal requirements, the president has traditionally provided informal notification of arms sales that will later require formal notification. ${ }^{19}$ That process originated from a 1976 Department of Defense commitment to provide such classified preliminary notifications ${ }^{20}$ and is intended to allow Congress to address potential concerns confidentially, protecting bilateral relations with potential recipient countries and ensuring that Congress will approve the later sale. ${ }^{21}$ However, "[i]f a committee 'raises significant concerns about a sale or [export] license,' the State Department 'will typically extend the review period until [Congress] can resolve those concerns." 22 Congress has used this informal process to freeze or hold numerous arms sales to the Saudi-led coalition, citing humanitarian concerns. ${ }^{23}$

The AECA allows the president to waive the formal congressional review requirements if he certifies "that an emergency exists which requires the proposed sale in the national security interest of the United States" and provides a "detailed justification for his determination."24 Acting on behalf of the president, Pompeo declared an emergency under that exception in May 2019, thereby bypassing congressional review of twenty-two arms sales packages to Saudi Arabia, the UAE, and Jordan, worth a total of $\$ 8.1$ billion. ${ }^{25}$ Of the twenty-two

${ }^{17}$ Specifically, the president must provide "to the Speaker of the House of Representatives, the Committee on Foreign Affairs of the House of Representatives, and to the chairman of the Committee on Foreign Relations of the Senate" 30 days advance notice "in the case of any letter of offer to sell any defense articles or services ... for $\$ 50,000,000$ or more, any design and construction services for $\$ 200,000,000$ or more, or any major defense equipment for $\$ 14,000,000$ or more," though there are shorter windows and higher value thresholds for sales to NATO members, Japan, Australia, South Korea, Israel, and New Zealand. 22 U.S.C. \$ 2776(b). For more on the congressional arms review process, see Paul K. Kerr, Cong. Research Serv., R31675, Arms Sales: Congressional Review Process 1-2 (July 17, 2020), available at https://fas.org/sgp/crs/weapons/RL31675. pdf [https://perma.cc/V37M-TSMH].

${ }^{18}$ See 22 U.S.C. $\$ 2776$ (b); KERR, supra note 17, at 3-6. Congress has "never successfully blocked a proposed arms sale by use of a joint resolution of disapproval." KeRR, supra note 17, at 6 .

${ }^{19}$ In practice, the State Department provides informal notification on behalf of the president. KeRR, supra note 17 , at 1 .

${ }^{20} \mathrm{Id}$. at 1 (citing Letter from Lt. Gen. H.M. Fish, USAF, Director, Defense Security Assistance Agency, to Senator Hubert H. Humphrey, Senate Committee on Foreign Relations (Feb. 18, 1976)).

${ }^{21}$ KerR, supra note 17, at 1 (citing Tina Kaidanow, Acting Assistant Secretary of State, "Foreign Military Sales: Process and Policy" Statement Before the Subcommittee on Terrorism, Nonproliferation and Trade, House Foreign Affairs Committee (June 15, 2017)); Michael LaForgia, Edward Wong \& Eric Schmitt, Trump Administration May End Congressional Review of Foreign Arms Sales, N.Y. Times (June 25, 2020), at https:// www.nytimes.com/2020/06/25/us/politics/trump-congress-arms-sales.html. 21.

${ }^{22}$ KerR, supra note 17, at 1 (quoting Kaidanow, supra note 21); see also LaForgia, Wong \& Schmitt, supra note

${ }^{23}$ Off. of Inspector Gen., supra note 1, at 5; LaForgia, Wong \& Schmitt, supra note 21.

2422 U.S.C. $\$ 2776(\mathrm{~b})$.

${ }^{25}$ Off. of Inspector Gen., supra note 1, at 7; U.S. Dep't of State Press Release, Emergency Notification of Arms Sales to Jordan, the United Arab Emirates, and Saudi Arabia (May 24, 2019), at https://www.state.gov/ emergency-notification-of-arms-sales-to-jordan-the-united-arab-emirates-and-saudi-arabia [https://perma.cc/ 94QG-UJFL]; see also Helene Cooper, Edward Wong \& Catie Edmonson, Trump Circumvents Congress to Sell Weapons to Middle East Allies, N.Y. Times (May 24, 2019), at https://www.nytimes.com/2019/05/24/world/middleeast/trump-troop-increase-middle-east-iran.html. 
packages, Congress had previously frozen fifteen under the informal review process. ${ }^{26}$ Pompeo justified the emergency declaration on the grounds that the sales were necessary to "support our allies, enhance Middle East stability, and help these nations to deter and defend themselves from the Islamic Republic of Iran," noting "[ $t]$ hese national security concerns have been exacerbated by many months of Congressional delay in addressing these critical requirements, and have called into doubt our reliability as a provider of defense capabilities, opening opportunities for U.S. adversaries to exploit." 27

The House and Senate passed three joint resolutions with bipartisan support in an attempt to disapprove the arms sales, ${ }^{28}$ but Trump vetoed all of them. ${ }^{29}$ The Senate was unable to override the vetoes. ${ }^{30}$ With these three vetoes and the veto related to the WPR resolution discussed above, four of Trump's eight vetoes during his presidency to date have dealt directly with the conflict in Yemen or arms sales to Saudi Arabia. ${ }^{31}$ The State Department and Department of Defense are now reportedly considering ending the longstanding informal review process - a move that would further limit Congress's ability to delay or prevent arms sales. ${ }^{32}$

Pompeo's emergency declaration also prompted Congress to request that the State Department IG investigate the State Department's role in arms sales. ${ }^{33}$ The then-State Department IG Steve A. Linick, who was appointed by President Obama in 2013, opened the investigation, but Trump fired him in May 2020 - a move that prompted three congressional committees to review whether the termination was retaliatory. ${ }^{34}$ During the hearings, Linick testified that two State Department officials had attempted to pressure him into ending the arms sales investigation, including the Acting Legal Adviser Marik String, who had helped Pompeo prepare the emergency declaration. ${ }^{35}$

After Linick's removal, Acting IG Diana R. Shaw took over the investigation and released a redacted version of the report to Congress in August 2020. ${ }^{36}$ The report explained,

${ }^{26}$ Off. OF InSPECTOR Gen., supra note 1, at 7.

${ }^{27}$ U.S. Dep't of State Press Release, supra note 25.

${ }^{28}$ S.J. Res. 36, 116th Cong. (2020); S.J. Res. 37, 116th Cong. (2020); S.J. Res. 38, 116th Cong. (2020); KerR, supra note 17 , at 7.

${ }^{29}$ S. Doc. No. 116-7 (2019); S. Doc. No. 116-8 (2019); S. Doc. No. 116-9 (2019).

${ }^{30}$ U.S. Senate, supra note 16.

${ }^{31} \mathrm{Id}$.

${ }^{32}$ LaForgia, Wong \& Schmitt, supra note 21.

${ }^{33}$ Letter from Elizabeth Warren, United States Senator (D-MA), \& Ted W. Lieu, Member of Congress (D-CA), to Steve A. Linick, State Department Inspector General (June 11, 2019); Off. Of Inspector Gen., supra note 1 , at 7 .

${ }^{34}$ Edward Wong, Michael LaForgia \& Lara Jakes, Pompeo Aide Who Pushed Saudi Arms Sale Said to Have Pressured Inspector General, N.Y. TIMES (June 10, 2020), at https://www.nytimes.com/2020/06/10/us/politics/ pompeo-inspector-general-saudi-arms.html.

${ }^{35} \mathrm{Id}$.

${ }^{36}$ Following Linick's departure, Stephen Akard took over as the acting State Department IG but recused himself from the arms sales investigation. OfF. OF INSPECTOR GeN., supra note 1, at 13. Akard resigned three months later with no explanation. Pranshu Verma \& Edward Wong, Another Inspector General Resigns Amid Questions About Pompeo, N.Y. Times (Aug. 5, 2020), at https://www.nytimes.com/2020/08/05/us/politics/inspector-general-pompeo-state.html. The redactions sparked additional controversy. The State Department based the redactions on concerns regarding executive privilege, the deliberative process exemption, and sensitive but unclassified information. Shaw noted that the redactions to the classified annex "withheld significant information... necessary to understand [the State Department IG]'s finding and recommendation," but said that the IG's office "[was] not in a position to overrule the assertion." Diana Shaw, Cover Letter to OfF. OF 
The AECA affords the President or Secretary considerable discretion in determining what constitutes an emergency. Moreover, the AECA does not define the term "emergency." Accordingly, [the IG] did not evaluate whether the Iranian malign threats cited in the Secretary's May 2019 certification and associated memorandum of justification constituted an emergency, nor did [the IG] make any assessment of the policy decisions underlying the arms transfers and the associated emergency. ${ }^{37}$

The report "determined that the emergency certification was executed in accordance with the requirements of the AECA," 38 but "that the Department did not fully assess risks and implement mitigation measures to reduce civilian casualties and legal concerns associated with the transfer of [precision-guided munitions] included in the Secretary's May 2019 emergency certification." 39 The IG further "found the [State] Department regularly approved arms transfers to Saudi Arabia and the [UAE] that fell below AECA thresholds that trigger notification to Congress," despite the fact that "[ $t]$ hese approvals included items such as [precision-guided munitions] components on which Congress had placed holds in cases where the transfers reached the thresholds requiring congressional notification." 40 The report's only recommendation, which deals with civilian casualties, is contained within the classified annex. ${ }^{41}$

The Trump administration has also acted to circumvent international restrictions on arms sales contained in the Missile Technology Control Regime (MTCR). Established by the G-7 in 1987, the MTCR is "an informal political understanding among states that seek to limit the proliferation of missiles and missile technology." 42 Although initially focused on proliferation of nuclear weapons, the MTCR, which currently has thirty-five member states, has expanded "to a focus on the proliferation of missiles for the delivery of all types of weapons of mass destruction (WMD), i.e., nuclear, chemical and biological weapons." 43 The MTCR establishes a "common export policy," set out in the MTCR Guidelines, ${ }^{44}$ which is then applied to items listed in the "MTCR Equipment, Software, and Technology Annex." 45 The Annex is divided into two categories. Category I includes "items of greatest sensitivity," and member states commit to using "[p]articular restraint ... in the consideration of Category I transfers regardless of their purpose" and to a "strong presumption to deny such transfers." 46

InSPECTOR Gen., supra note 1. Chairman of the House Foreign Affairs Committee Representative Eliot Engel (DNY) promised that "[w] e will review the entire product with an eye toward ensuring that the classified annex hasn't been used to bury important or possibly incriminating information.” Edward Wong \& Michael LaForgia, Watchdog Says State Dept. Failed to Limit Civilian Deaths from Saudi Arms Sales, N.Y. Times (Aug. 11, 2020), at https://www.nytimes.com/2020/08/11/us/politics/pompeo-state-inspector-general-saudi-weapons-civiliancasualties.html.

37 OfF. OF InsPector Gen., supra note 1, at 1-2.

${ }^{38} I d$. at 2.

${ }^{39} I d$. at 2,11 .

${ }^{40} I d$. at $2,11-12$.

${ }^{41} \mathrm{Id}$. at 11.

${ }^{42}$ Missile Technology Control Regime, Frequently Asked Questions, at https://mtcr.info/frequently-asked-questions-faqs [https://perma.cc/9FW4-L7Y5] [hereinafter Frequently Asked Questions].

${ }^{43} \mathrm{Id}$.

${ }^{44}$ Id.; Missile Technology Control Regime, Guidelines for Sensitive Missile-Relevant Transfers, at https://mtcr. info/guidelines-for-sensitive-missile-relevant-transfers [https://perma.cc/ME9C-E4ZW] [hereinafter Guidelines].

${ }^{45}$ Missile Technology Control Regime, Equipment, Software, and Technology Annex 7 (Oct. 11, 2019), at https://mtcr.info/mtcr-annex [https://perma.cc/XZG9-85M8] [hereinafter Annex].

${ }^{46}$ Guidelines, supra note 44. 
As relevant here, Category I includes "[c] omplete unmanned aerial vehicle systems ... capable of delivering at least a $500 \mathrm{~kg}$ 'payload' to a 'range' of at least $300 \mathrm{~km},{ }^{47}$ as well as "their major complete subsystems . . . and related software and technology." 48 Partner countries "have greater flexibility in the treatment of Category II transfer applications," though they "still agree[] to exercise restraint" in their transfer. ${ }^{49}$

Although the MTCR operates by consensus, ${ }^{50}$ the Trump administration unilaterally reinterpreted the MTCR to reclassify certain UAS from Category I to Category II. ${ }^{51}$ The change affects the MQ-9 Reaper, produced by General Atomics, which recently "stepped up efforts to lobby [U.S.] officials to bypass" the MTCR. ${ }^{52}$ In a press release, the White House explained:

While the $[\mathrm{MTCR}]$ is critical in slowing proliferation and promoting peace and security, it is in dire need of modernization as it applies to UAS. . . Not only do these outdated standards give an unfair advantage to countries outside of the MTCR and hurt United States industry, they also hinder our deterrence capability abroad by handicapping our partners and allies with subpar technology. More than two years of discussion with MTCR partners were unable to produce consensus on this overdue reform. Therefore, the President has decided to invoke our national discretion to treat a carefully selected subset of MTCR Category I UAS, which cannot travel faster than 800 kilometers per hour, as Category II. As such, the United States has determined that it will overcome the MTCR's strong presumption of denial for this UAS subset. ${ }^{53}$

The press release also noted that UAS exports remain "subject to the rigorous review criteria outlined in the UAS Export Policy, the Conventional Arms Transfer Policy, and the [AECA], as well as the specific nonproliferation criteria identified in the MTCR Guidelines," and that "approving or denying a UAS sale to any country is a whole-of-government decision and takes into account our national security, nonproliferation, and foreign policy objectives, as well as the purchasing country's ability to responsibly use and safeguard United States-origin technology." 54 The press release concluded by noting that " $\mathrm{t}] \mathrm{he}$ United States looks forward to all MTCR nations joining us in adopting this new standard." 55

In response, a bipartisan group of senators introduced a bill to amend the AECA to codify portions of the MTCR and ban the "export, transfer, or trade" of covered items to countries

${ }^{47}$ Annex, supra note 45, at 16.

${ }^{48}$ Frequently Asked Questions, supra note 42.

${ }^{49}$ Missile Technology Control Regime, MTCR Guidelines and the Equipment, Software and Technology Annex, at https://mtcr.info/mtcr-guidelines [https://perma.cc/WHD8-PT68].

50 Frequently Asked Questions, supra note 42.

${ }^{51}$ White House Press Release, Statement from the Press Secretary on Unmanned Aerial Systems Exports (July 24, 2020), at https://www.whitehouse.gov/briefings-statements/statement-press-secretary-unmanned-aerial-systemsexports [https://perma.cc/LA6W-8ATN]. For additional background, see PAul K. Kerr, Cong. ResearCh SERV., IF10069, U.S.-Proposed Missile Technology Control Regime Changes (July 27, 2020), available at https:// fas.org/sgp/crs/nuke/IF11069.pdf [https://perma.cc/6JT4-M62X].

52 Edward Wong, Lawmakers Aim to Prevent Trump from Bypassing Ban on Armed Drone Sales, N.Y. TIMES (Aug. 6, 2020), at https:/www.nytimes.com/2020/08/06/us/politics/lawmakers-trump-armed-drone-sales.html.

53 White House Press Release, supra note 51.

${ }^{54} \mathrm{Id}$.

${ }^{55} \mathrm{Id}$. 
other than NATO allies, Australia, Israel, Japan, New Zealand, and South Korea. ${ }^{56}$ Specifically, the bill would cover UAS “(a) capable of delivering a payload of not less than 500 kilograms over a range of not less than 300 kilometers; or (b) described in item 1.A.2 of category I of the MTCR Annex." 57 Senator Christopher Murphy (D-CT), one of the bill's sponsors, observed that "the President's action will only further enable the Saudis to continue killing more innocent civilians in Yemen by supplying them with advanced U.S.made drones ... Congress can stop Trump in his tracks." 58 The bill has been referred to the Senate Foreign Relations Committee, ${ }^{59}$ but in the meantime, the Trump administration is moving forward with weapons sales under its new MTCR interpretation. On October 13, 2020, the State Department provided Congress with pre-notification of the intent to sell MQ-9 Reaper drones to Taiwan, ${ }^{60}$ and on November 10, 2020, the State Department provided Congress with formal notification of the intent to sell advanced drones and other arms to the UAE. ${ }^{61}$ On December 9, the Senate failed to advance joint resolutions to block the UAE sales, despite some bipartisan support. ${ }^{62}$

A September 2020 report from a panel of experts reporting to the UN Human Rights Council may fuel further congressional concerns about arms sales to members of the Saudi-led coalition. ${ }^{63}$ The report found "reasonable grounds" to believe that the parties to the conflict, including coalition members Saudi Arabia and the UAE, "are responsible for human rights violations" and "have committed a substantial number of violations of international humanitarian law," including violations of "the principles of distinction, proportionality and precaution that may amount to war crimes." 64 The report criticized the role of third parties, calling out Canada, France, Iran, the United Kingdom, and the United States for

56 S. 4474, 116th Cong. $\$ 73 \mathrm{C}(\mathrm{b})(2020)$; see also Wong, supra note 52.

57 S. 4474, 116th Cong. $\$ 73 C(c)(2020)$.

58 Wong, supra note 52.

${ }^{59}$ S.4474 - A Bill to Amend the Arms Export Control Act to Prohibit the Export of Certain Unmanned Aircraft Systems, U.S. CONGrESS (Aug. 6, 2020), at https://www.congress.gov/bill/116th-congress/senate-bill/4474/text [https://perma.cc/NPT9-NLA4].

${ }^{60}$ Mike Stone, Patricia Zengerle \& David Brunnstrom, Exclusive: White House Advances Drone and Missile Sales to Taiwan-Sources, ReuTERS (Oct. 13, 2020), at https://www.reuters.com/article/usa-taiwan-arms/exclusivewhite-house-advances-drone-and-missile-sales-to-taiwan-sources-idUSL1 N2H417P.

${ }^{61}$ U.S. Dep't of State Press Release, U.S. Approves Advanced Defense Capabilities for the United Arab Emirates (Nov. 10, 2020), at https://www.state.gov/u-s-approves-advanced-defense-capabilities-for-the-unitedarab-emirates [https://perma.cc/2AM7-UP2M]. Senators Robert Menendez (D-NJ), Christopher Murphy (D-CT), and Rand Paul (R-KY) have announced plans to introduce resolutions to attempt to block the sales. Patricia Zengerle \& Mike Stone, U.S. Senators Seek to Stop Trump's $\$ 23$ Billion in Arms Sales to UAE, REUTERS (Nov. 18, 2020), at https://www.reuters.com/article/usa-emirates-arms-sales-int/u-s-senators-seek-to-stoptrumps-23-billion-in-arms-sales-to-uae-idUSKBN27Y2YO.

62 See Karoun Demirjian, Trump on Course to Complete UAE Arms Deal after Senate Fails to Block Him, WASH. Post (Dec. 9, 2020), at https://www.washingtonpost.com/national-security/trump-uae-weapons-sales-senate/ 2020/12/09/ae9abca6-3a59-11eb-98c4-25dc9f4987e8_story.html; see also S.J. Res. 77, 116th Cong. (2020); S.J. Res. 78, 116th Cong. (2020).

63 Grp. of Eminent Int'l and Reg'l Experts on Yemen, Situation of Human Rights in Yemen, Including Violations and Abuses Since September 2014, UN Doc. A/HRC/45/6 (Sept. 28, 2020), available at https:// www.ohchr.org/Documents/HRBodies/HRCouncil/GEE-Yemen/2020-09-09-report.pdf [https://perma.cc/ 45SP-MFDH]; see also Michael LaForgia \& Edward Wong, War Crime Risk Grows for U.S. Over Saudi Strikes in Yemen, N.Y. Times (Sept. 14, 2020), at https:/www.nytimes.com/2020/09/14/us/politics/us-war-crimesyemen-saudi-arabia.html. For additional background on congressional concerns about potential U.S. liability for strikes by the Saudi-led coalition, see Daugirdas \& Mortenson, supra note 2, at 530-31.

${ }^{64}$ Grp. of Eminent Int'l and Reg'l Experts on Yemen, supra note 63, at 17. 
"continu[ing] their support of parties to the conflict, including through arms transfers, thereby helping to perpetuate the conflict." 65 The report argued that such states are "failing in their responsibilities to ensure respect for international humanitarian law," and that "such support may amount to aiding and assisting internationally wrongful acts in contravention of international law." 66 The report "calls upon the Security Council to refer the situation in Yemen to the" ICC and advocates for continued international discussions about a special international criminal tribunal for the Yemen crisis. ${ }^{67}$

${ }^{65} I d$. at 5 .

${ }^{66} \mathrm{Id}$. at $16-17$.

${ }^{67}$ Id. at 16; see also Missy Ryan, U.N. Report Calls for Alleged War Crimes in Yemen to Be Referred to International Criminal Court, WASH. POST (Sept. 10, 2020), at https://www.washingtonpost.com/national-security/un-reportcalls-for-alleged-war-crimes-in-yemen-to-be-referred-to-international-criminal-court/2020/09/10/3eb69194f369-11ea-9279-45d6bdfe145f_story.html. 